\title{
PENERAPAN METODE PERBANDINGAN EKSPONENSIAL (MPE) SEBAGAI ALTERNATIF UNTUK MENUNJANG PEMILIHAN KARYAWAN TERBAIK PADA PD. TIARAMAS GLASSINDO
}

\author{
Vanya Eka Syafitri ${ }^{1)}$, Humisar Hasugian ${ }^{2)}$ \\ ${ }^{1}$ Sistem Informasi, Fakultas Teknologi Informasi, Universitas Budi Luhur \\ ${ }^{1,2} \mathrm{JI}$. Raya Ciledug, Petukangan Utara, Kebayoran Lama, Jakarta Selatan 12260 \\ E-mail : vanyaesyafitri@gmail.com ${ }^{1)}$, humisar.hasugian@budiluhur.ac.id ${ }^{2)}$
}

\begin{abstract}
Abstrak
Penelitian yang penulis buat membahas tentang sistem penunjang keputusan pemilihan karyawan terbaik pada $P D$. Tiaramas Glassindo yang bertujuan untuk menghasilkan keputusan dalam pemilihan karyawan terbaik sesuai dengan kriteria pada PD. Tiaramas Glassindo. Masalah yang terjadi sekretaris mengalami kesulitan dalam proses pengolahan data dan nilai. Sedangkan direktur utama mengalami kesulitan dalam rekap nilai mengurutkan dari yang terbesar sampai yang terkecil yang hanya dilakukan sendiri mengakibatkan proses pemilihan karyawan terbaik belum maksimal dan membutuhkan waktu yang lama. Diperlukan suatu sistem penunjang keputusan (SPK) yang dapat memperhitungkan nilai karyawan dari setiap kriteria yang sudah ditentukan oleh PD. Tiaramas Glassindo untuk proses pengambilan keputusan. Menerapkan Metode Perbandingan Eksponensial (MPE) dengan menggunakan kriteria-kriteria yang sudah ditetapkan perusahaan yaitu kehadiran ditempat kerja, ketepatan waktu dalam menyelesaikan tugas, tanggung jawab dan profesionalitas dalam bekerja, kejujuran, dan komunikasi pada customer. Laporan yang dihasilkan dalam sistem ini adalah cetak karyawan terbaik yang akan diserahkan langsung secara pribadi kepada karyawan yang terpilih sebagai karyawan terbaik, laporan hasil karyawan terbaik yang menampilkan nilai data karyawan beserta keterangan terpilihnya karyawan menjadi karyawan terbaik atau tidak terpilih, laporan history nilai karyawan, dan laporan history karyawan terbaik dari tiap periode. Sistem penunjang keputusan pemilihan karyawan terbaik yang dibuat penulis menggunaan bahasa pemprograman PHP Framework Laravel, serta menggunakan database MySQL yang dijalankan di sistem operasi Windows.
\end{abstract}

Kata kunci: SPK, DSS, MPE, Karyawan Terbaik.

\section{PENDAHULUAN}

Karyawan merupakan pekerja yang telah memiliki kontrak perjanjian kerja dengan perusahaan dalam jangka waktu yang sudah ditentukan, dan mampu melaksanakan pekerjaan serta memberikan hasil kerjanya kepada pengusaha atau instansi dimana hasil kerjanya itu sesuai dengan profesi atau pekerjaan atas keahlian sebagai matapencarian, dan karyawan memperoleh balas layanan berbentuk upah serta kompensasikompensasi yang lainnya.

Dalam suatu perusahaan sumber daya manusia (SDM) berperan penting bagi keberlangsungan perusahaan tersebut sehingga upah/gaji merupakan hal wajib yang diberikan perusahaan kepada karyawannya, disamping upah/gaji biasanya perusahaan juga memberikan bonus tambahan bagi para karyawannya yang terpilih menjadi karyawan terbaik dan juga sebagai salah satu cara agar karyawannya tetap bekerja dengan giat yang nantinya kinerja karyawan akan dinilai dan dipilih sebagai karyawan terbaik.

PD. Tiaramas Glassindo adalah sebuah usaha kecil menengah yang bergerak dibidang finishing bangunan yang didirikan untuk melayani kebutuhan akan jasa dan solusi dalam membangun, PD. Tiaramas Glassindo juga menerapkan pemilihan karyawan terbaik untuk meningkatkan kualitas kinerja karyawan di perusahaan.

Namun Pemilihan karyawan terbaik yang berjalan saat ini metode yang digunakan PD. Tiaramas Glassindo untuk pemilihan karyawan terbaik kurang tepat, direktur juga sulit untuk menentukan karyawan terbaik dikarenakan harus mengumpulkan data nilai karyawan dan merekap data nilai karyawan terlebih dahulu, dan penentuan karyawan terbaik bersifat subjektif dikarenakan sering terjadi salah perhitungan. Oleh karena itu diperlukan suatu sistem penunjang keputusan yang dapat memperhitungkan semua kriteria yang mendukung proses pengambilan keputusan guna membantu PD. Tiaramas Glassindo dalam mengambil keputusan.

Untuk menunjang sistem keputusan tersebut maka penulis menggunakan suatu metode yang dapat digunakan untuk membantu proses pengambilan keputusan yang tepat dan akurat. Metode yang dipakai dalam mendukung keputusan pemilihan karyawan terbaik pada PD. Tiaramas Glassindo adalah Metode Perbandingan 
Eksponensial (MPE). Sebagai usaha penulis untuk memberikan solusi atas masalah yang dialami oleh PD. Tiaramas Glassindo.

\section{PENELITIAN SEBELUMNYA}

\subsection{Sistem Pendukung Keputusan}

Sistem Pendukung Keputusan menurut Randi V. Palit [1] adalah suatu sistem interaktif yang mendukung keputusan dalam proses pengambilan keputusan melalui alternatif-alternatif yang diperoleh dari hasil pengolahan data, informasi dan rancangan model. Sistem Pendukung Keputusan merupakan penggabungan sumber-sumber kecerdasan individu dengan kemampuan komponen untuk memperbaiki kualitas keputusan Dengan pengertian sebelumnya dapat.

\subsection{Karyawan}

Karyawan menurut Handri Murdianto [2] adalah setiap orang yang menyediakan jasa (baik dalam bentuk pikiran maupun dalam bentuk tenaga) dan mendapatkan balas jasa ataupun kompensasi yang besarannya telah ditentukan terlebih dahulu.

\subsection{Metode Perbandingan Eksponensial (MPE)}

Metode Perbandingan Exponensial (MPE) menurut Rohmat Indra Borman [3] adalah salah satu metode dari Decision Support System (DSS) yang digunakan untuk menentukan urutan prioritas alternatif keputusan dengan kriteria jamak. Dengan perhitungan secara eksponensial, perbedaan nilai antara kriteria dapat dibedakan tergantung kepada kemampuan orang yang menilai. Untuk menggunakan metode MPE terdapat beberpa langkah.

$$
\begin{aligned}
& \text { Total Nilai }\left(T N_{i}\right)=\Sigma_{J=1}^{m}\left(R K_{i j}\right)^{T k k j} \\
& \text { Keterangan : } \\
& \text { Tni : Total nilai alternatif ke-i } \\
& \text { Rkij : Derajat kepentingan relatif kriteria } \\
& \text { ke-j pada pilihan keputusan ke-i } \\
& \text { TKKj : Derajat kepentingan kriteria } \\
& \text { keputusan ke-j TKKJ>0; bulat } \\
& \mathrm{N} \quad \text { : Jumlah pilihan keputusan } \\
& \text { M : Jumlah kriteria keputusan }
\end{aligned}
$$

\subsection{Prototype}

Penelitian ini menggunakan pengembangan sistem prototipe (prototyping). Metode ini tepat untuk digunakan dalam menyelesaikan masalah kesalahpahaman antara user dan analis yang terjadi akibat user tidak mampu mendefinisikan secara jelas kebutuhannya.

Prototyping menurut Neni Purawati [4] adalah pengembangan yang cepat dan pengujian terhadap model kerja (prototipe) dari aplikasi baru melalui proses interaksi dan berulang-ulang yang biasa digunakan ahli sistem informasi dan ahli bisnis. Prototyping disebut juga desain aplikasi cepat (rapid application design/RAD) karena menyederhanakan dan mempercepat desain system.

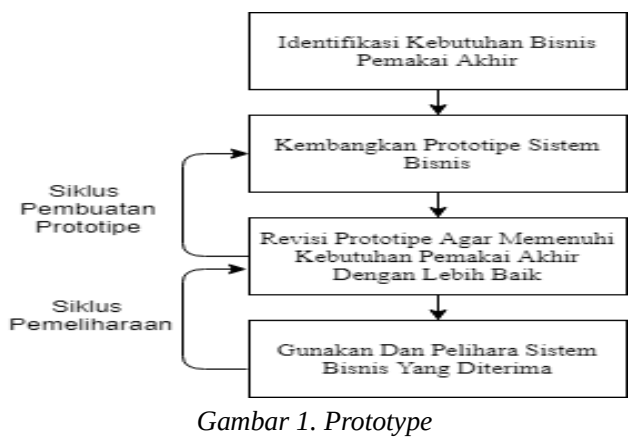

\subsection{Studi Literatur}

Penelitian ini dilakukan berdasarkan referensi jurnal lain sesuai dengan permasalahan yang dihadapi. Adapun penelitian sebelumnya yang berkaitan dengan pemilihan karyawan terbaik, diantaranya menggunakan metode AHP dan SAW yang dilakukan oleh Humisar Hasugian dan Esa Putra [5] mempunyai kriteria tanggung jawab, kerjasama, SOP, kedisiplinan, kehadiran. Dengan hasil nilai akhir 0,95 yang dimiliki oleh karyawan yang bernama Excelthalia.

Penelitian selanjutnya menggunakan metode SAW dilakukan oleh Handri Murdianto [2] yang mempunya kriteria pengetahuan pekerjaan, inisiatif pekerjaan, produktifitas pekerjaan, komunikasi, kerjasama, tanggung jawab, kehadiran. Dengan nilai akhir 0,75 dengan karyawan yang bernama Edi Sukemi.

Kemudian penelitian selanjutnya yang menggunakan metode Promethee dilakukan oleh Setya Pami [6] yang mempunyai kriteria jujur, penampilan, kepribadian, kehadiran, loyalitas, tanggung jawab, disiplin, prestasi. Dengan nilai akhir 0,29 yang dimiliki oleh alternatif A4.

\section{METODE PENELITIAN}

Dalam mengerjakan sebuah penelitian ini penulis harus menyusun tahapan pengumpulan data seperti pengamatan, wawancara, studi kepustakaan, analisis dokumen.

\section{a. Pengamatan (Observation)}

Kegiatan ini dilakukan secara langsung ke PD. Tiaramas Glassindo untuk mengumpulkan data yang berkaitan dengan proses penentuan karyawan terbaik.

\section{b. Wawancara (Interview)}

Wawancara dilakukan dengan direktur utama dengan PD. Tiaramas Glassindo sebagai bagian untuk memperoleh informasi dalam proses 
penentuan karyawan terbaik pada PD. Tiaramas Glassindo. Dari wawancara penulis juga mendapatkan dokumen-dokumen yang digunakan dalam pengembangan sistem penunjang keputusan pemilihan karyawan terbaik.

\section{c. Studi Kepustakaan}

Dilakukan dengan cara membaca buku-buku atau $e$-book yang berkaitan dengan teori pemilihan karyawan terbaik, teori decision support system (DSS), teori Metode Perbandingan Eksponensial (MPE), teori metodologi berorientasi objek dan teori-teori lainnya yang berkaitan untuk membantu proses pembuatannya sistem penunjang keputusan ini.

\section{d. Analisis Dokumen}

Penulis melakukan analisis dokumen berjalan yang ada di PD. Tiaramas Glassindo untuk memperoleh informasi yang akan digunakan untuk membantu proses pembuatan sistem yang akan dibuat.

\section{HASIL DAN PEMBAHASAN}

\subsection{Analisa Masalah}

Dalam penelitian ini penulis menemukan masalah yang terjadi saat pengambilan keputusan yang dilandasi beberapa faktor manusia yaitu subjektifnya direktur utama dalam mengambil keputusan, faktor prosses pembuatan laporan yang sangat lama, faktor metode perhitungan yang kurang tepat. Sebab akibat digambarkan dalam fishbone diagram berikut ini:

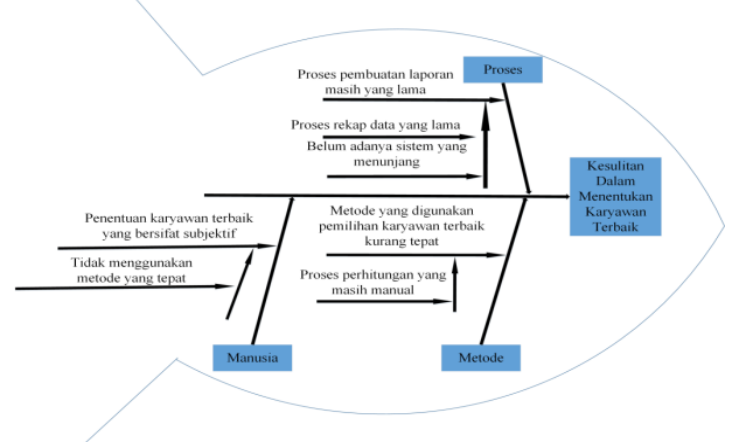

Gambar 2. Fishbone Diagram

\subsection{Proses Bisnis}

a. PD. Tiaramas Glassindo melakukan penilaian karyawan terbaik setiap enam bulan sekali dalam setahun. Penilaian dilakukan berdasarkan kriteria yang telah ditetapkan inilah yang akan menjadi pertimbangan penentu karyawan terbaik. Mandor melakukan pemantauan selama enam bulan sekali, mandor akan mengisi form penilaian karyawan sesuai dengan kinerja karyawan selama bekerja dan memberikan form survei lapangan kepada customer sebagai penilaian tambahan untuk karyawan yang telah bekerja.

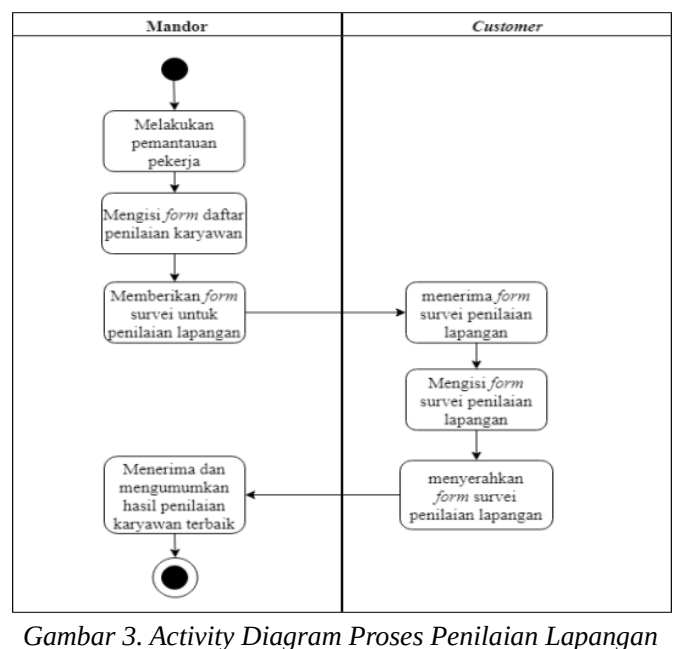

b. Setelah dinilai mandor memberikan kepada sekretaris untuk dihitung hasil kinerja karyawan selama enam bulan, setelah mendapatkan hasil perhitungan sekretaris menyerahkan kepada direktur utama untuk memilih dan mengurutkan dari nilai yang terbesar sampai yang terkecil dan menandatangani dokumen penilaian karyawan terbaik, setelah itu memberikan kepada sekretaris untuk dibuatkan laporan hasil pemilihan karyawan terbaik, karyawan dengan hasil tertinggi akan ditetapkan sebagai karyawan terbaik di PD. Tiaramas Glassindo

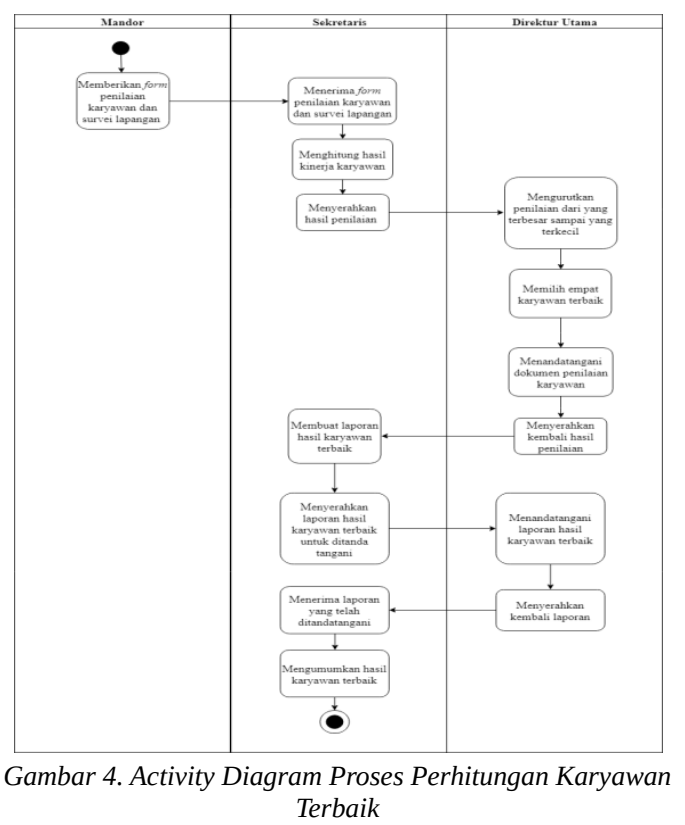




\subsection{Metode Perbandingan Eksponensial}

Metode Perbandingan Exponensial (MPE) yang digunakan untuk menentukan karyawan terbaik yang ada didalam penelitian ini, dengan cara menghitung nilai kinerja karyawan yang akan dipangkatkan dengan masing masing bobot kriteria. Setelah hasil sudah dipangkatkan lalu dijumlahkan, hasil alternatif yang terbesar akan terpilih sebagai karyawan terbaik di PD. Tiaramas Glassindo.

a. Identifikasi Tujuan

Berikut adalah alternatif data yang digunakan untuk proses perhitungan menggunakan metode perbandingan eksponensial:
1) Amin
2) Asep
3) Irwan
4) Agung
5) Sofan

b. Identifikasi Kriteria

Berikut adalah kriteria-kriteria dan bobot yang penulis dalam dari hasil wawancara dengan direktur utama yang nantinya karyawan akan mempunyai nilai dari setiap kriteria dan akan dijumlahkan dengan bobot yang sudah ditentukan dalam proses pengambil keputusan.

\begin{tabular}{|c|l|c|}
\hline $\begin{array}{l}\text { Kode } \\
\text { Kriteria }\end{array}$ & Kriteria & Bobot \\
\hline 1. & Kehadiran & 2 \\
\hline 2. & Ketepatan & 2 \\
\hline 3. & $\begin{array}{l}\text { Tanggung jawab \& } \\
\text { profesionalitas }\end{array}$ & 2 \\
\hline 4. & Kejujuran & 2 \\
\hline 5. & Komunikasi & 2 \\
\hline
\end{tabular}

Gambar 5. Ketentuan Kriteria

c. Pengolahan Data

Berikut ini adalah hasil perhitungan yang dibuat penulis dengan menggunakan metode perbandingan eksponensial. Karyawan yang memiliki nilai disetiap kriteria akan dipangkankan dengan masing-masing bobot dari setiap kriteria:

a.Total nilai untuk Amin

$$
\mathrm{TN}_{1}=(9 \wedge 2)+(8 \wedge 2)+(8 \wedge 2)+(9 \wedge 2)+(9 \wedge 2)
$$$$
=371
$$

b. Total nilai untuk Irwan

$$
\mathrm{TN}_{2}=(9 \wedge 2)+(8 \wedge 2)+(8 \wedge 2)+(9 \wedge 2)+(7 \wedge 2)
$$$$
=339
$$

c.Total nilai untuk Sofan

$$
\mathrm{TN}_{3}=(9 \wedge 2)+(8 \wedge 2)+(6 \wedge 2)+(9 \wedge 2)+(7 \wedge 2)
$$

$$
=311
$$

d. Total nilai untuk Agung

$$
\mathrm{TN}_{2}=(8 \wedge 2)+(6 \wedge 2)+(7 \wedge 2)+(9 \wedge 2)+(8 \wedge 2)
$$$$
=292
$$

e.Total nilai untuk Asep

$$
\mathrm{TN}_{2}=(9 \wedge 2)+(7 \wedge 2)+(6 \wedge 2)+(9 \wedge 2)+(5 \wedge 2)
$$$$
=272
$$

Dari perhitungan diatas dapat disimpulkan bahwa nilai terbesar diperoleh oleh Amin sebagai karyawan terbaik dengan ranking 1.

\subsection{Rancangan Basis Data}

Dalam menganalisa kebutuhan penulis membuat ERD sebagai bentuk gambaran dari database yang digunakan untuk menyimpan semua data dalam proses pengambilan keputusan karyawan terbaik, sebagai berikut:

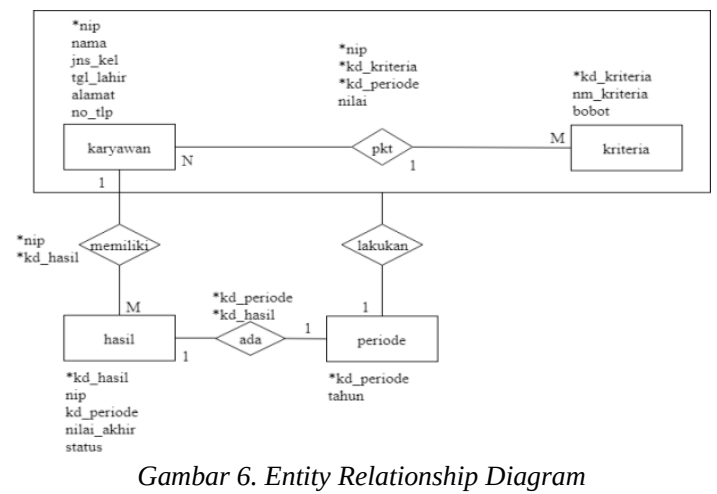

\subsection{Perancangan Sistem}

a. Use case Diagram menggambarkan kebutuhan user yang digunakan untuk menginput data yang digunakan untuk proses pengambilan keputusan.

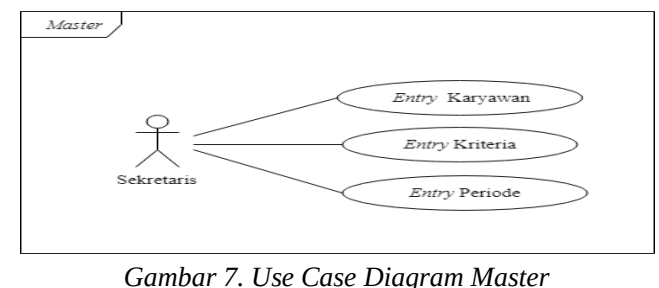

b. Use case Diagram ini menggambarkan tentang user dalam pengumput nilai kinerja karyawan yang nantinya akan dihitung dengan rumus MPE didalam sistem yang akan dikembangkan, dan hasil terbesar akan terpilih sebagai karyawan terbaik.

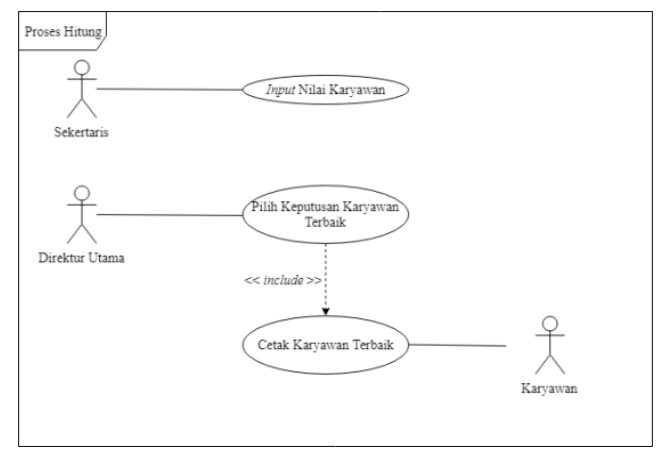

Gambar 8. Use Case Diagram Proses Hitung

c. Use case Diagram ini menggambarkan sebuah laporan akhir yang digunakan direktur utama 
untuk mengevaluasi kinerja karyawan yang ada di PD. Tiaramas Glassindo.

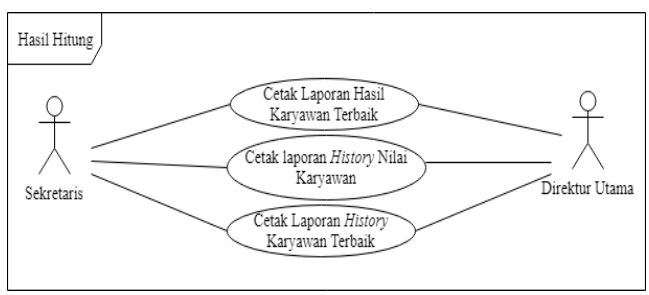

Gambar 9. Use Case Diagram Hasil Hitung

\subsection{Rancangan Layar}

\section{a. Input Data Karyawan}

Form ini digunakan untuk meng-input data karyawan. Pada form entry data karyawan ini terdapat nip karyawan, nama, jenis kelamin, tanggal lahir, alamat, no telpon, klik tambah data input nip karyawan, nama karyawan, jenis kelamin, tanggal lahir, alamat, no telpon lalu masukan kedalam textbox.

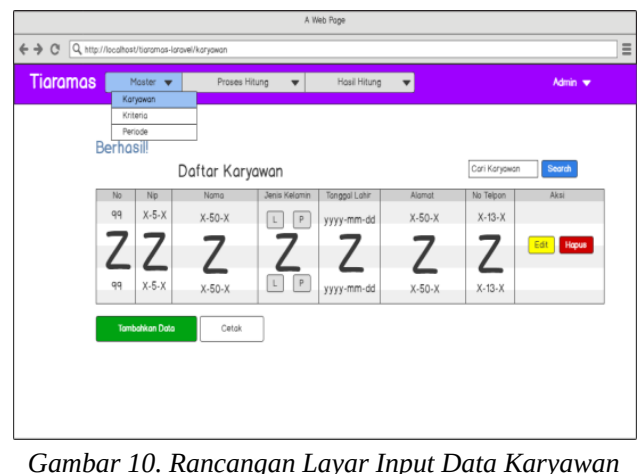

\section{b. Input Data Kriteria}

Pada form entry data kriteria ini terdapat kode kriteria dimana terurut secara autonumber, nama kriteria dan juga bobot kriteria, klik tambah data lalu input nama kriteria, dan juga bobot masukan kedalam textbox.

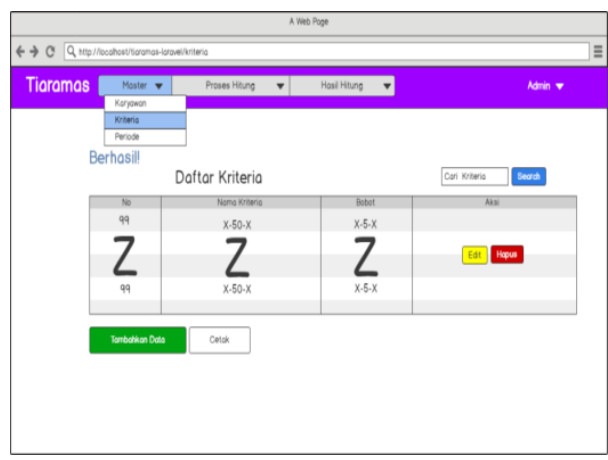

Gambar 11. Rancangan layar Input Data Kriteria

\section{c. Input Data Periode}

Form ini digunakan untuk meng-input data periode. Terdapat dua kali periode dalam satu tahun di PD. Tiaramas Glassindo. Pada form entry data periode ini terdapat kode periode dimana terurut secara autonumber, tahun periode, klik tambah data lalu input tahun periode masukan kedalam textbox.

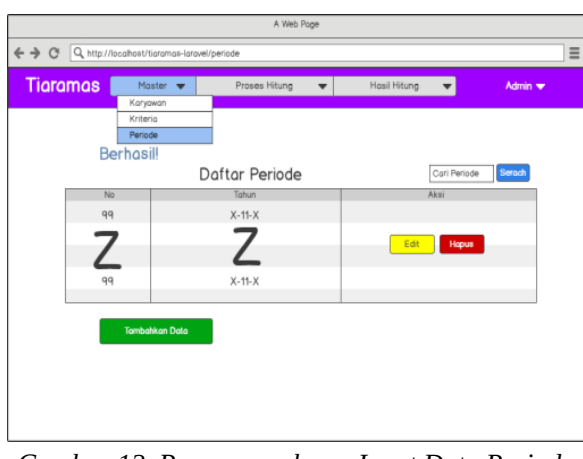

Gambar 12. Rancangan layar Input Data Periode

\section{d. Input Nilai Karyawan}

Pada form input nilai karyawan terdapat button combobox untuk menampilkan nama karyawan yang sudah di input untuk dipilih, tahun periode dengan button combobox, input masing masing nilai karyawan sesuai dengan kriteria yang sudah tersedia, nilai yang di input tidak bisa lebih dari range 1-10. Untuk menyimpan data terdapat botton masukan nilai.

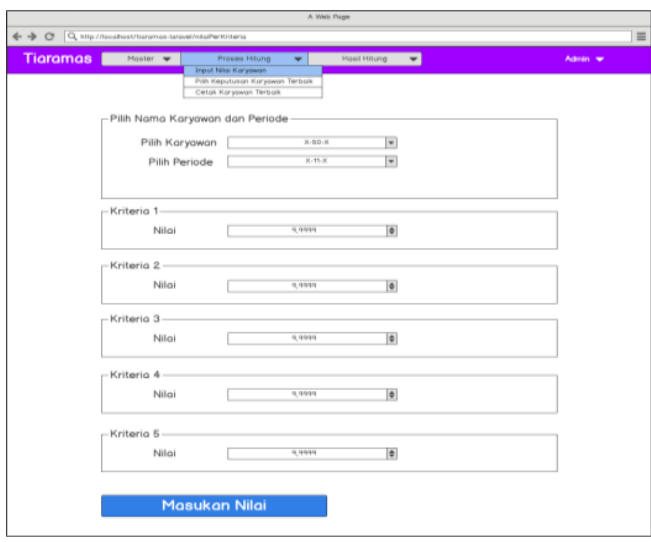

Gambar 13. Rancangan Layar Input Nilai Karyawan

\section{e. Input Keputusan Terbaik}

Form ini digunakan untuk pilih keputusan karyawan terbaik terdapat pada menubar proses hitung. Pada form pilih keputusan karyawan terbaik terlebih dahulu memilih periode yang pemilihan karyawannya ingin ditampilkan, lalu klik button choice untuk memilih siapa karyawan yang akan menjadi karyawan terbaik di PD. Tiaramas Glassindo, klik simpan untuk menyimpan hasil keputusan karyawan terbaik. 


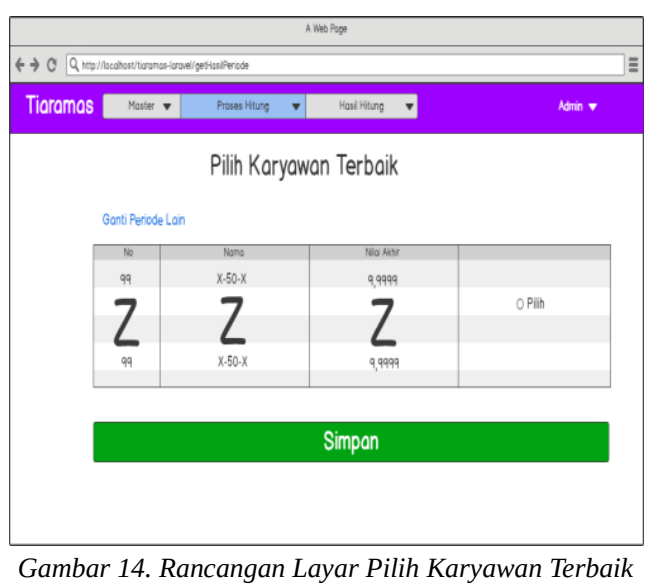

f. Cetak Keputusan Karyawan Terbaik

Form cetak karyawan terbaik untuk menampilkan satu hasil cetakan dari pemilihan karyawan terbaik yang akan diserahkan langsung secara pribadi kepada karyawan yang telah terpilih menjadi karyawan terbaik menurut periode yang telah dipilih.

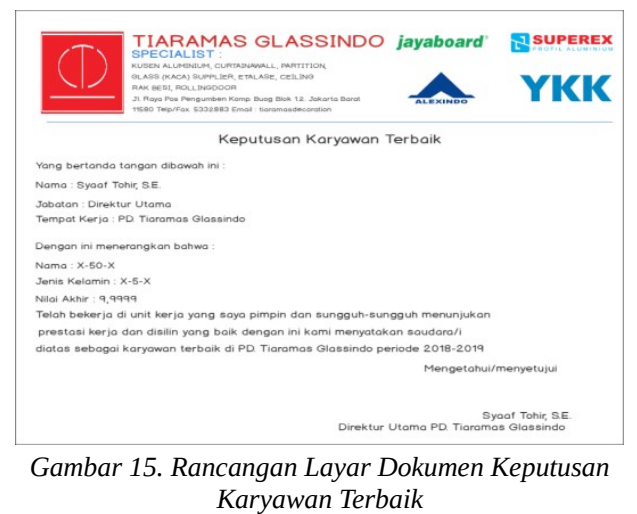

g. Laporan Hasil Pemilihan Karyawan Terbaik

Form cetak hasil karyawan terbaik untuk menampilkan laporan nilai akhir karyawan beserta keterangan terpilih atau tidak terpilih menurut periode yang telah dipilih.

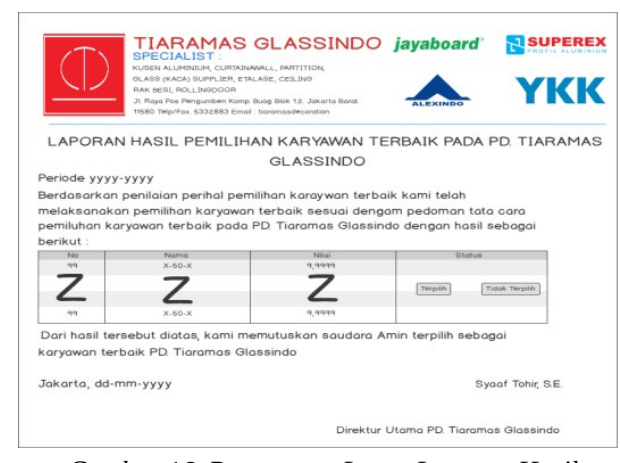

Gambar 16. Rancangan Layar Laporan Hasil Pemilihan Karyawan Terbaik

\section{h. Laporan History Nilai Karyawan}

Form cetak history karyawan untuk menampilkan laporan nilai karyawan secara detail sampai hasil nilai akhir.

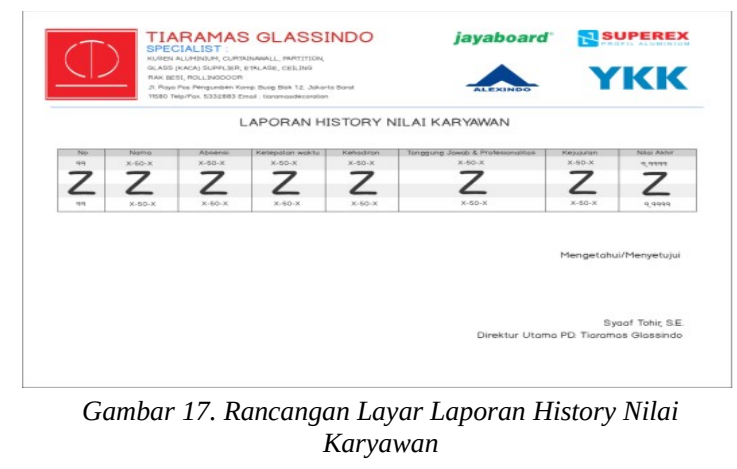

i. Laporan History Karyawan Terbaik

Form Menu Cetak History Karyawan Terbaik untuk menampilkan laporan yang isinya semua karyawan yang telah terpilih menjadi karyawan terbaik dan diurutkan berdasarkan periodenya.

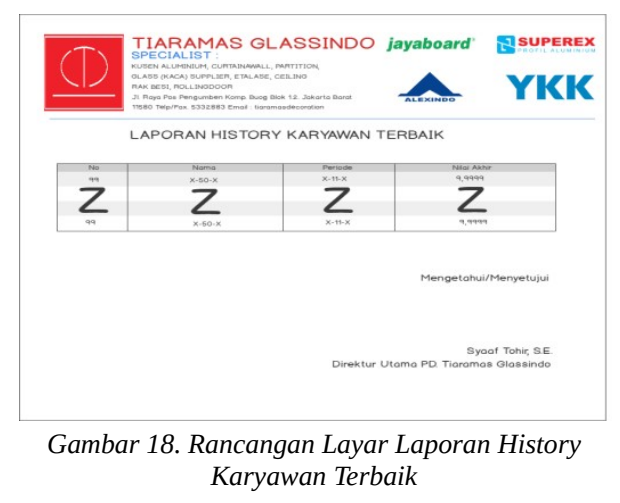

\section{KESIMPULAN}

Berdasarkan penelitian yang telah dilakukan dari PD. Tiaramas Glassindo, maka terdapat kesimpulan yang dapat diambil, yaitu :

a. Dengan adanya sistem penunjang keputusan karyawan terbaik diharapkan dapat membantu sekertaris di PD. Tiaramas Glassindo dalam melakukan inputan data karyawan dan nilai karyawan, memperhitungkan nilai karyawan, dan laporan dari hasil penilaian yang dilakukan dalam satu sistem, sehingga meminimalisir terjadinya kesalahan penginputan dan dapat mempercepat proses pengambilan keputusan pemilihan karyawan terbaik.

b. Untuk menerapkan metode perbandingan eksponensial (MPE) pada sistem pendukung keputusam karyawan terbaik terdapat beberapa tahapan diantaranya menilai kinerja karyawan, menentukan nilai karyawan per kriteria, menentukan bobot disetiap kriteria, dan 
menghitung nilai karyawan dengan bobot yang sudah ditentukan dan hasil akhir yang terbesar akan terpilih sebagai karyawan terbaik di PD. Tiaramas Glasssindo.

c. Dengan adanya sistem penunjang keputusan ini maka proses pemilihan karyawan terbaik lebih tepat. Sehingga proses penilaian karyawan lebih cepat dan terhindar dari adanya subjektifitas dalam proses pemilihan karyawan terbaik.

\section{DAFTAR PUSTAKA}

[1] R. V Palit, Y. D. Y. Rindengan, and A. S. M. Lumenta, "Rancangan Sistem Informasi Keuangan Gereja Berbasis Web Di Jemaat GMIM Bukit Moria Malalayang," E-Journal Tek. Elektro dan Komput., vol. 4, no. 7, pp. 1-7, 2015.

[2] H. Murdianto, D. M. Khairina, and H. R. Hatta, "Sistem Pendukung Keputusan Pemilihan Karyawan Terbaik Per Triwulan PT. Cahaya Fajar Kaltim PLTU Embalut Tanjung Batu Menggunakan Metode Simple Additive Weighting," Pros. Semin. Ilmu Komput. dan Teknol. Inf., vol. 1, no. 1, pp. 24-29, 2016.

[3] F. H. Rohmat Indra Borman, "Penerapan Metode Perbandingan Eksponensial (MPE) Dalam Sistem Pendukung Keputusan Penerimaan Beasiswa Siswa Berprestasi Pada SMK XYZ,” J. Comput. Eng. Syst. Sci., vol. 3, no. 1, pp. 17-22, 2018.

[4] N. Purwati and H. Kurniawan, "Studi Pengembangan Prototype Knowledge Management Pada Pengecekan Judul Tugas Akhir atau Skripsi Fakultas Ilmu Komputer IBI Darmajaya," Konf. Nas. Sist. Inform., vol. 2, no. 1, pp. 9-10, 2015.

[5] H. Hasugian and E. Putra, "Sistem Penunjang Keputusan Pemilihan Pegawai Terbaik Dengan Metode AHP dan SAW Pada PT. Sukma Jaya Mandiri,” J. Telemat. MKOM, vol. 9, no. 3, pp. 102107, 2017.

[6] S. Pami, "Sistem Pendukung Keputusan Pemilihan Karyawan terbaik dengan Metode Promethee (Studi Kasus: PT. Karya Abadi Mandiri),” J. Pelita Inform., vol. 16, no. 3, pp. 298-301, 2017. 